信州上田を中心とする木綿工業见関する地理的考察

一一原料移入地域の一例——

\author{
黒、崎千, 晴 \\ [五万分の一上田・坂城・和田・小諸各困幅参照]
}

\title{
(1) まえがき
}

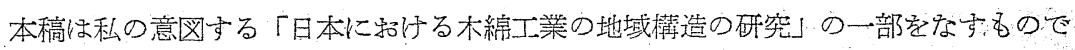
孪。

ここに检討する信州小具郡の旧上田領を中心として展開されて来た木締工業は原料移 大地域に拈ける生産活動の一例で岕る。且，安政開港とそれに続く産業革命の進展乙共

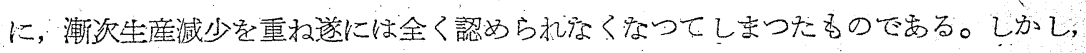
その発生の時期は彷来の諸研究に示されたものよりも相当に古いと推察され，原料そ求 めた地域の中には全国的な綿花生産の核心地域が合められ，藩政初期からそれそ直接交 渉を保のて来たと認められるものでもある物資移動の諸制約を最す強く受ける内陸地

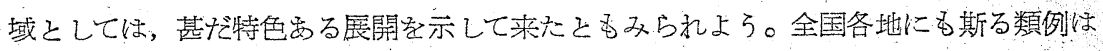
求められるかと思らが，管見の限りではとのよろなるのに対する検討す極く稀かと思ら。 し分し, 在来産業の主要な地位を占め, 且, 既に解消してしまつた各地の諸工業の展開 した跡をたどり，各地域に蚂けるそれらの位置付けを果さずして，現在みられる日本の 各地方の諸活動を検討寸ることは果して可能になるものであろらか。少なくとも，現在 の諸活動はこれら在来のものを背景や素地として展開して来た結果ですることからすれ ばそその背景に䦛する检討も当然の要請と考えざるを得ない。ここに本稿の主眼を牤い て检討を進めよう。

信濃川の上流・中流は千曲川之㭔ばれる。小県郡はその流域の小盈地で, 旧城卡たる 上田市学核之して地形的にあ気候的にる一単元をなしている。この小登地に需つて, 暴 政期から認められる旧町村は166を数え, その大半の116 ケ町村は上田領, 残余は小諸, 岩村田の各潘領や爾津・矢沢等の旗本領技び幕府直轄領でるる。 
第 1 表

\begin{tabular}{|c|c|}
\hline 組 名 & 村 \\
\hline 田 中 & 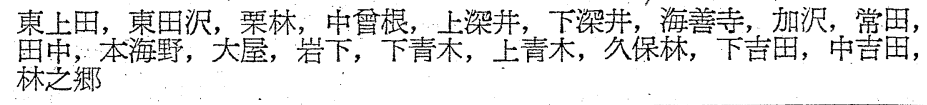 \\
\hline 洗 馬 & 上原; 中原, 下原, 横尾, 真田, 横沢, 大日向, 曲尾, 上洗馬, 㪕井沢 \\
\hline 国分寺 & $\begin{array}{l}\text { 伊勢工, 新屋, 金剛寺, 長鳥, 大久保, 野竹, 䇠井, 岩門, 染屋, 黒坪, } \\
\text { 上沢, 国分寺, }\end{array}$ \\
\hline 上田町 & 横町，海野町，鍛治町，原町，柳町，田町，紺屋町 \\
\hline 塩 尼 & 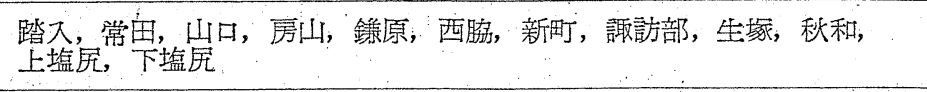 \\
\hline 武 石 & 沖, 鳥屋, 下武石, 上武石, 下本入, 上本入, 小沢根, 余里 \\
\hline 盐 田 & 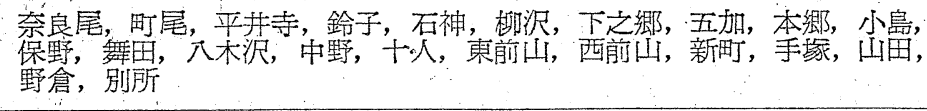 \\
\hline 小 㤐 & 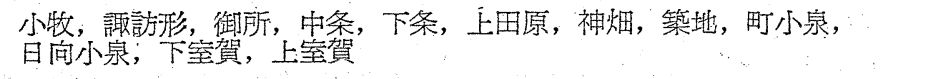 \\
\hline 浦 野 & 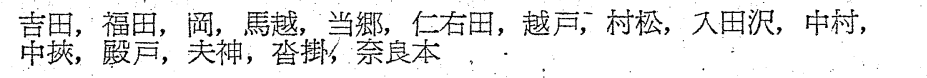 \\
\hline
\end{tabular}

上田領の村々は上田城下町を除き，各々地勢によつて次の各組に区分されていた。即

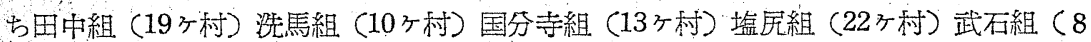
ヶ村) 塩田組（22ケ村）小泉組（12ヶ村）浦野組 (15ヶ村) がそれで，第1表はこの区 分を示したものである。この内, 塩㞔組は城下周辺の村々で, 塩田・小泉・浦野の各組

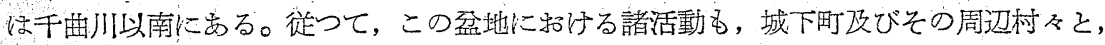
千曲川以南の塩田平を中心とする各村々との間には種々の相違が認められて来たすので \$。

\section{（2）潘政初期 の 諸動向}

藩政期から明治初期に到る間，信州の各小盈地にありては，伊那谷・松本平の如く藩 政初期には綿花の生産があつて後には中絶した地域，或は善光寺平の如く穈長頃から明 治に到る末で相当の作付けがみられた地域等る出る。しかし，小県郡においては眀治以 降も藩政期に市つても全く綿花の生産は認められ㚮のである。上田領全域としては善光 
寺平南部に旧村 8 ケ村学るが, これらの村タから上田城下送られる綿花は息く篠巻と して半製品の形で出荷されたものであり，善光寺平における篠巻移出の一核心であつた 松代より上王へ出荷の起源は元交年間 (1736～39) より遡り得ない。にも拘らず, 後述 する如く，小県郡上田領村々に焉つては既に宝永 3 年 (1706)に合計 25 人の繶打職人が 畫上げられる程であつた。即ち，当時既に繰綿か実綿のますの原料を移入して加工する 生産が村々に扔いても寒現していたことになる。しかもこれらの綿打職人は1な村に 9 人・4 人と相当まるまつて特り，中には「渡り細工る仕わ」と明記されているのも少 くない。また，紺屋職人は更に多く 68 人(内城下は 20 人)す書上汿られ，「かな染」と 傍記される村落居住者も相当に認められる程でも昰つた。それ故, これらの綿打や紺屋 等の存在を必要とする如き木綿生産が宝永 3 年当時既に党まれていた專実は否定できず, それは上田城下やその周辺の村々のみならず，小県郡下村々の一般的活動であつたとさ え認められる。全くの原料移入地域で, しかも近距離の綿花生産地からは篠巻以外の入 荷は認められなかつた小県郡に㐫つて, 城下町は勿諭, その他の村落ても繰綿 $\rightarrow$ 篠巻 より系 (か度糸) 一染色一機械 $\rightarrow$ 綿という形の木綿生産が斯様な規模の下に展開され ていた事実は甚だ注目すべきで岕ろら。

それ故，これらの木綿工業が如何なる契機の下に発生したが，その発生の時期は何時 頃からか，その間の諸㨻情は如何なるすのか，等々が第一の関心事となる。残念ながら， 現在までに求め得た各資料によつては発生の時期もその間の諸事情も全く不分明之言了 他ない。唯，求められた資料によつて断定できることは，少くとす蕒永20年 (1642) 或 はそれよりる以前から，上田城下の商人の間に「繰綿仲間」と唱える同業組合類似の組 織がみられたことである。この繰綿仲間は既にこの当時にあつてす, 全国的な綿花生産 の核心たる上方地方之直接の取引関係をるち，年々件間の代美が上方へ出張して原料買 付に当つて来たことが知られる。の卒らず，筧交19年 (1670) の送状にみられる如く， 大和の郡山積出の繰綿10駩の場合は，代金・諸脚支び江州米原までの運䡠を郡山の綿間 屋が立替えて，半年後の支払といら信用貸を与えられる程度の賛模の商人さえあつた事 実が認められる。但，当時，上田城下には何人の仲閏方离つたか，それらはどの範囲を 製品の売先としていたか，年間の取引量はどんな規模をるつていたか, 木綿生産の構造 はどのよちなるのか等々は全く判明しない。いずれにしてる；藩政の初期において，信 州の山間盈地の小城下の商人達の間にこのよろな組織と，斯る遠距離の原料産地との直 接関係が存在したことは否定できず，殆んぞ輸送の大半を陸路に佳存するにる拘らず， 
斯る原料移動がなされたのである。この移動はその後にもみられるから：これがこの当 時の例外的事例でつたとは到底認め難い。彷つて,これまで経済史的立場からなされて 来を藩政期の物資交流に関する所見や諸生産活動に対する所見む, この小県郡に関する 限り、そのまま適用することは一応控えるべきるのと思う。

一方, 城下以外の村々の動きについてはやや後の宝永 3 年 (1706) のるのが初見で, これ以前に閣しては全く不明である。この年，新領主が徵した各村の明細帳によると， 領内の殆んぞ全部の村々に出つては，莶間の女榢として「木綿」「布木繶」「木綿布」「木

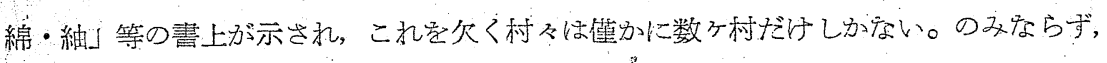
維屋の存在する村ふは 18 ヶ村, 綿打が 6 ケ村るからて, 中には両者合計 17 人(房山) 15 人 (常出) 12 人 (西脇) 等の村さえある。これらの中でも綿職人の場合は西脇・房山・ 常田・踏大等の上田城下周辺の村々に集中的に認められ, 上述の繰綿仲間々の密接な関 連を推測するに足るかとみられ，城下商人の規制下にある下請工業の存在を䀧示するる のと思5。しかしながら，紺屋の場合は，城下 20 人・城下周辺の各村 32 人と集中する 以外にむ $1 \sim 2$ 人を有する村々が㿽地内部に点在し，その中には「かな染」職人る少く

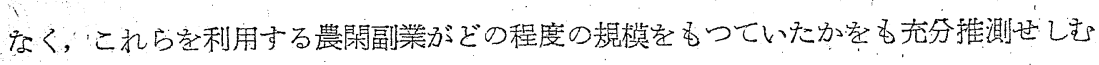
るすのである。再言すれば,この当時, 小県郡下に展開されていた木綿工業は城下の繰 綿仲間定中核として各町々や城下周辺の村々に集中的に営まれていた問屋制家内工業々，

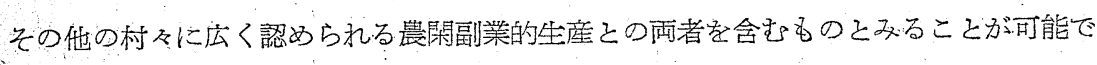
あり，その製品は篠巻・白木綿のみならず，縞木綿程度の複雑な工程を有するものも相

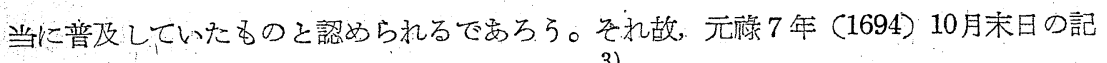
録に木綿 500 反, 内 389 は両町市, 111 以紹売と示さる如き程度が, 1 日の取引量とし て報告されているのる充乲肯定できる。そ.して，これらの諸動向の発展からずれば，亨 保14年 (1726) 城下の木綿商 58 名（海野町 28 ・原町 16 ・横町 6 -柳町 4 -木町 3 ・田 町1)の連名を以て「近年木綿户幅不足御座候二付他所江売兼……綿商仕市者氏方

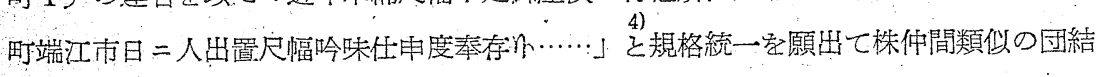
を示すに到すのる至極当然のことです岁ろら。

以上の検討により，小県郡下に敌ける木綿工業の藩政初期から中期に到る間の動きる

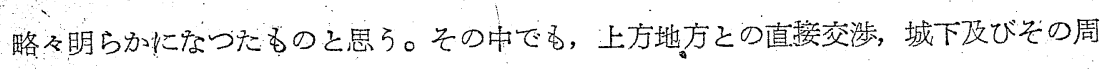
辺に怙ける下請的生産, 領内全般の農間稼などが特に注目される。上方地方との交渉に

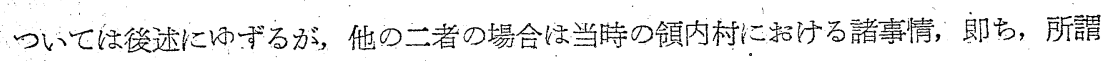


農民層の分化の程度・農業生産力とその構造・農間稼全般の挸模や内容等々の解明を要 すると思う。ぬず㖘業生産力でせるが，上田領では二三の村々の他は本田畑は検地さえ なく貫高を称していたので，その石盛や反別さえ不眀である。しがし，盆地南部の塽谷

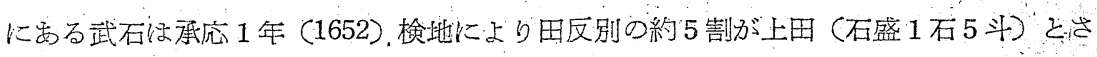

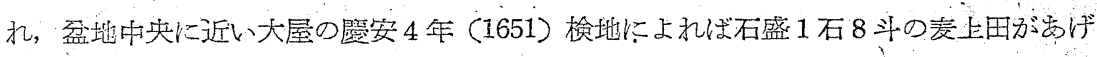
られることからすると，小県盈地の生産力は全国平均空相当に上备るるので, 盈地中央 の塩田平その仳に恵つては相当古くから水田 2 毛作さえ一般化していたものと認められ

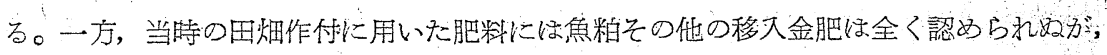
大半の村々では湌虫の書上がみられ，上田縞・上田紬等の原料生産が普及していたとみ られる。乙かて；紬生産を明示する村々は鏵かに 4 乃村 (上下塩居・秋和・常田) を数

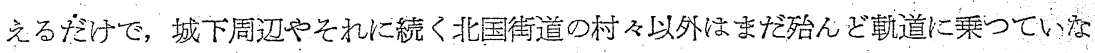
がたものと思ら。

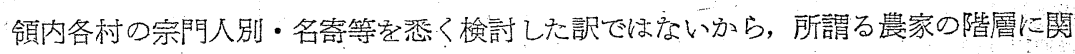
する詳細は殆んど不期と言了他皂い。しかし，宝永の村明細帳に本百姓・水态の別を明 示する郝々 96 ヶ村についてみると，その戸数合計 6487 月中で水吞とされているすのが 2704戸も要り，領内裳家の約 4 割強は全くの小作人だつたことになる。各村毎にこの率 を求めてみると，盆地周辺の山間部では $5 \sim 8$ 割前後が水吞である村々が多く，中央部 では一般に $2 \sim 3$ 割定し, 城下周逝がまた 6 制近くの高率を示している。享保以前に 出つてる，斯る程度の複雑さがみられることは，全国的視野からしても甚仡しい特別事 例かも知机ないし，山間部孔城下周辺とでは水吞とされている人々の性格が塞りた内容

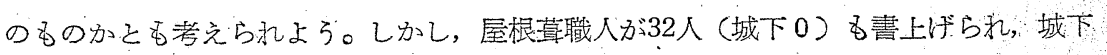
周辺の 14 人は別としても領内各村に 18 人が分散していること，その中には荁や放。 渡り細工も仕於」が少なからず認められる事実からすれば，当時既に村々にあつても， 一般的には屋根更えの共同作業たる「結」組織ぶずつかり崩れてしまい，各户が銘タに 屋根更えをする程に到つていたとみられるので出る。即ち，領内村々に怙ける社会構成 が斯る共同作業を廃する程になつていたからこそ,これら屋根職人の存在を許すように もなつていたのであり，水吞と書上げられたるのの大半は交字通りの近世的性格を具え ていたと認めざる表得ないので出る。また, 斯る複雑な社会楧成と小作人層の存在が背 景々なつて，始めて原料移大の問屋制家内工業の展開が可能であつたとみるべきでりり， 極度に自給的生蓙が強制さ秃下層農民が中世的意識の下に地主層に䍮属しているが如き 
場合々は到底認められ欢であるつ。且，斯る社会構成が前提にめつたからこそ，農間副 業的な木綿生産が領内全般にわたつて普改し，「かな染紺屋」の如き在村職人を散在さ せ得るまでに到つたるのとるみられる。

な报，以上の諸動向を更に判然と裏付けるるのは城下町以外に存在する商人や職人の 分布である。第 2 表は村明細帳にある商人札 ( 1 人 1 年 2 分上納) や職人等の書上より 算出して示したもので，城下各町・城下周辺村々改びその他領内各村々一応区分して招 いた。この第 2 表により全般の諸動向は充分把握できると思ろが，城下周辺村々ぜけで す城下の商人の65\%に当る商人が居住し，その他の村々の商人が城下の气れょり $54 \%$ る

第 2 表 小県郡上田領村々の農間稼（宝永 3 年）

\begin{tabular}{|c|c|c|c|c|c|c|c|c|c|c|}
\hline & $5 \square+5$ & 塩尼 & 組 & 千曹 & 川以北 & 各組 & $千$ & 由川 以 & 火南各 & - 組 \\
\hline & & 城下周辺 & その他 & 国分寺 & 洗馬 & 田中 & 塩田 & 小豕 & 浦野 & 武石 \\
\hline 商 人 & 今人 & 人ิ & र & $1 \hat{15}$ & 人 & $\hat{16}$ & 人) & 人 & 人 & 人 \\
\hline 造' 酒 & 24 & 4 & 0 & 1 & 0 & 3 & 3 & 0 & 1 & 0 \\
\hline 紺，屋 & 20 & 32 & 2 & 1 & 0 & 1 & 10 & 4 & 2 & 0 \\
\hline 綿 打 & 0 & 22 & 1 & 2 & 0 & 0 & 0 & 0 & 0 & 0 \\
\hline 鍛，治 & 32 & 24 & 1 & 3 & 1 & 3 & 6 & 4 & 2 & 3 \\
\hline 大 I & 9 & 38 & 1 & 3 & 1 & 0 & 4 & 2 & 4 & 0 \\
\hline 屋根蒙 & 0 & 14 & 4 & 0 & 0 & 3 & 0 & 9 & 0 & 0 \\
\hline 桶 屋 & 19 & 16 & 1 & 1 & 0 & 2 & .0 & 0 & 5 & 2 \\
\hline 木 㻊 & 2 & 4 & $0^{\circ}$ & 0 & 2 & 0 & 2 & 1 & 1 & 1 \\
\hline 馬 喰 & 0 & 0 & 0 & 0 & 1 & 13 & 0 & 0 & 5 & 6 \\
\hline 馬 医 & 2 & 0 & 1 & 0 & 1 & 3 & 3 & 2 & 0 & 1 \\
\hline その他 & 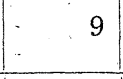 & 31. & 0 & 0 & 1 & 0 & 0 & 1. & 0 & $\begin{array}{r}10 \\
1 \\
\end{array}$ \\
\hline 合 計 & 233 & 261 & 18 & 26 - & 27 & 44 & 73 & 52 & 64 & 23 \\
\hline 紙 溜 & 0 & 5 & 1 & 0 & 11 & 12 & 10 & 5 & 256 & 45 \\
\hline 総三数 & 352 & 763 & 219 & 482 & 1064 & 820 & 1348 & 840 & 1062 & 491 \\
\hline
\end{tabular}

（上田藩村明細帳より算出） 
多い事実は，上述の検討を充分肯定せしむるに足るるのと思う。勿論，これらの取引能 力や規模はまだ比較になら程ですうたかと考えるが，それにしてる甚だしい数を示し ている。往つて, 城下町商人の有力層はこれら在鄉商人の活動を背景として来たものと みられ，それが享保14年の木綿取締り出願にも示される如く，城下や領内への売さばき， よりも「他所江売…」ることを眼自とする活動ともなつたとみることができるのである。

\section{（3）原料移入にみられる諸動向}

1, 上方加らの原料移大

江戸時代も後期となれば,，初期改び中期に示された如き発展を背景として，いよいよ 目覚ましい展開を認めることができる。これらの動きは全国的に認められる諸工業生産 のそれ之，時期的にも略々同期に展開され，当時，北信州一円の主要工業の地位を占め ていたものである。且，城下町上田を中核とする木綿生産は，北信州子ける木綿工業の 中心地域ともいろべき性格を具備するに到つた，とさえ認め得るようになつて来る。

即ち，原料集荷の面では，初期の動向を継承する为如くに，上方地方，就中，和州郡 山からの綿荷入荷が著るしく，その一回の取引量も初期の十数倍に到している。また， それと共に大阪積出の篠巻も年々大荷するよろになり，その一回の大荷量は繰綿と略々 同量か或はそれ以上をる示している。これらの運送経路は，大阪上り伏見ま厄河舟，大 津まて陸送，米原まで湖上運送，それより名古屋に到り，中馬荷物として松本経由で上 田へ運ばれるのが常例かとみられ，中には大坦辺より河舟により名古屋へ送られた場合 もみられる。これらの大荷が年々どの程度であつたかは不明といら他ないが，安永 9 年 (1780) 1 月の伏見荷間屋橉屋より上田の綿屋万助宛送状には篠巻 175 䭾, 繰綿80馹と女 り, 天明 1 年 (1781) 4 月の名古屋小牧町荷問屋上り綿屋万助宛のそれには繰綿 277 䭾, 篠巻 291 䭾, 同年 7 月の送状には繰綿 105 䭾, 篠巻 119 䭾とある。綿屋厅助はこの当特 上田市中屈指の豪商で票るが，これらの送状に示された数量からみて，大凡，ぞのさら な規模の活動を展開していたか子判明するるのと思う。

これが上方との直接取引の一班であるが，斯る取引を可能とした背景は当時小県郡下 全般にみられた上田縞・上田紬等の絹織物生産にあるとみられ, 事実, 綿屋万助宛の京 都絹問屋美濃屋忠右衛門上りの売仕切に上れば，上田領内産の絹織物の他，上州・秩父・ 下野辺の生産とみられる絹織物が年々 2000 2800 正程度も出荷されていたことが判明 する。即ち，綿屋万助の場合は小県郡下は勿論，関東西北部の絹織物まです買集めて， 
それを京都へ送りそのの代金を以て郡山・高田(共に大和)・大阪边上り篠巻・繰綿を求 めて, 上田へ運ぶといら往復貿易に似た取引に従つていたものである。斯る规模の紹問 屋だけがこの当時の上田城下太物仲間を棈成していたので勿論ないが; その仲間の中 にはこのよろな商人も含まれていたのであり，长の資本之取引涀模が太物仲間の中核的

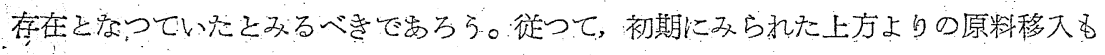
後期のそれと同様に小県産の絹々上方産の繰締との往復が条件となつていたからとる2 ら礼るが, その確証はまだ求めていないので, 断定は控えて物ころ。いずれにしてもこ れが上方地方よりの原料移大の内容で要つたので耑る。再言すれば，上方からの原料移

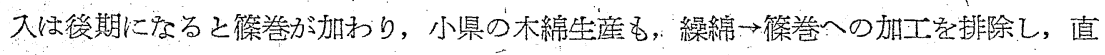
ちに撚系生産に取掛る上らな形も加つて来たとみられるのである。且, その取引先は奈 良盈地内部の地方的集荷市場のみならず，大阪の如き全国的中心市場をる合文，全国的 の原料価格の変動赴直接に受けるまでに到つたと認められよろ。

•.，奥綿・・骤訪・甲州篠巻の大荷

一方, 先にむふ玑た如く, この盆地に最子近い綿花生産地たる善光寺平南部からの原 料移入は，元文年間を機化急增したとみられる。善光寺平の綿花生産はその北限を岳北 の木島周辺とみることができるが，この平では既に㦄長年間 (1596〜1614) からとの作 付が㐫り，善光寺平各市場はいずれる木綿荷物の集荷を主眼とする程であつた。その中， 上田への再出荷がみられるのは松代・善光寺・稻荷山・福島等の南部各市場で，松代の 如きは 55 人(交化13) るの綿商人がみられる。松代領から木綿荷物の上田出荷は元交年 間 (1736〜40)が最初の上万で，篠巻のままでの出荷は更に約 10 年後からといら。また， 川中島・善光寺・福島等の善光寺平南部一帯より上田市場への直移出は面に20年後から 開始とるされている。これらの善光寺産綿花は上田市場で一括して「奥紹」と唱えられ， 悉く木綿か篠巻の形で出荷され，実綿や繰綿のまをで移出されたものは全くない。即ち， 実綿，繰綿の形で出荷する程の大量は生産されなかつたから，いずれる農間稼や下請加 エたより一応の加工を経て後の移出であるしかし, この程度の生産ですても, 明和 年間 (1764 71) には年タ 5 ～万雨之推定されるすの他領の各地へ送つていたとい ろ程で要つた。

これらの奥綿の他にす上田市場へ集荷される篠巻類がある。その一は䯅訪盈地の各村

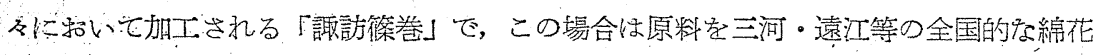
生産の中心地域に求めている。従つて, 諏訪の場合は善光寺平のそれとは異り, 綿花は 


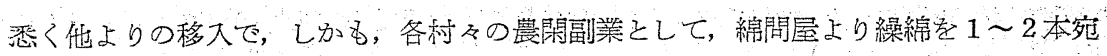

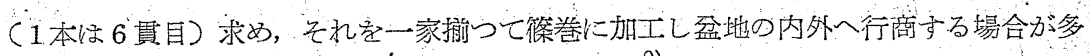

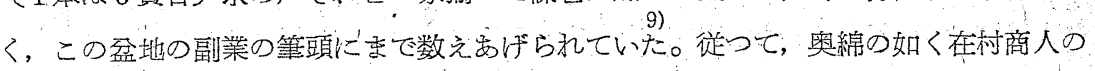
手で集荷されたるのが上田一出荷されるのではなく，㖘家の自家加工品が小量宛上田の 綿商人の許へ運ばれていたといろ。それ故か，上田における骤訪篠巻は量目不足が多く，

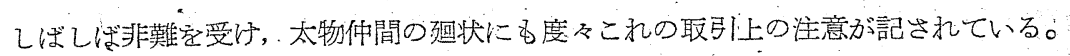

また，当時上田に集荷された篠巻の中には「申州篠巻」の名す岕げられる。即ち，申 府登地に招いて生産された綿花を篠巻の形で上田へ運んだもので要る。この甲府盈地に 抢ける綿花生座やその加工についてはまだ未調查のため詳細は不明であるが，上田市場 では諏訪箖巻と略々同格こざれていたらしく，量目不足に対する非難や注意も共通のよ ろである。

以上の㭘討に上つて明らかになつたよろに，後期，小県盈地の木綿工業に対する原料

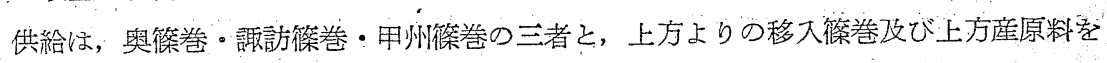

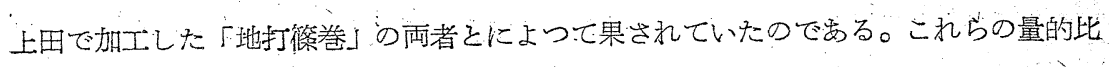
率の詳細は不明であるが，奥篠巻・上方篠巻改び地打鳋巻の三者が主体になつたとみら

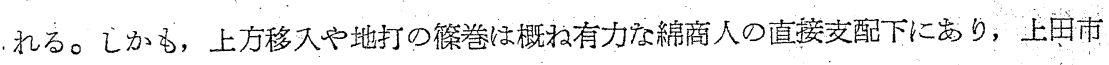
場の需給調節に相当な影留を与えていたのであろろ。何となれば，上述の如き大量の移 大が, 輸送上の交障や運顀その他の諸掛りを考慮に扣いても; 上田市場の一有力商人に よつて年々実施される事実から推測でさるように，恐らく上方座の篠巻はその他のるの 上り相当安值で上田に到着したとみられるからである。また，上方産繰綿の加工む全， 問屋制家内工業によるもので, 共々に太物仲間の手中にあら，その他の篠巻の市場価格 の調節に大きな役割を果していたとみて美交えなからう。

\section{八，移大原料に対する上田市場の統制}

斯る推察名一層よく裏付けるるのは文化 1 年(1804) 9 月から上田城下の太物仲間を主 体としてなされた諸統制である。これは当初奥篠巻を主な対象としたるので, 第一に奥 綿商人を水内郡川北組，松代組，善光寺組，福島組の4 組合に組織させ，その各々を 綿売衆宿 (太物仲間の中から出す) に所属さ交ている。且，これらの綿売衆宿は篠巻の 取引市場とさ礼えらしく，ここで目方学欧め検印を行い，その際，改料として売人；買， 人より各々10交宛(104把大 1 本につき)徵取したものである。同時に太物仲間の協定と

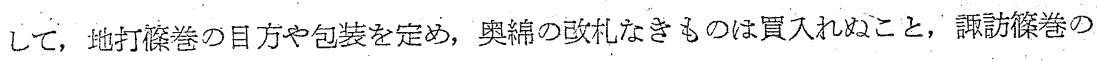


場合は最寄の仲間が立合つて調べることなどが离つた。更に，交化 4 年には更級郡下に める上田領の綿売衆のために稻荷山組の組織を認め, 一方, 同じ更級郡の水鉋而部 (共 に上田領〉の新組申入れる稻山組へ加入をる否定する程になつていた。また，同年の12 月には諏訪・甲州の両篠巻をる改所 (綿売衆宿) を定めて検印することを協定しており， 斯様にして上田市場集荷の篠巻は愁く太物仲間の続制下に挌かれることになつたので㐫 る。斯る協定が相手方にる受容される程に強力であつた事実は，上田城下゙を中核とする 小県郡下の木綿工業が如何なる展開をを示していたかを判然と示するのであらら。換言 寸れば，善光寺平・諏訪盈地・甲府盈地等の木綿生産に関保する人タが常に上田市場を 念頙に扮かざるを得ない程の規模を示し，原料集荷地として強力な買手市場を形成して いたことになり，しかも，その買付価格調節は上方よりの直移入原料によつて相当有利 に果し得たすのとみられる。

この綿売衆に対する㚘制の中，目方改めだけは太物仲閒の間に設けられた改所によつ てこの後子強力に実施されていた。唯, 新組設立に対する反対や妨げは交化 5 年に到つ て, 上田藩よりの達しにより禁止されるようになつた。即ち，「……是の為外荷物を美 芰に相成様二而八又売之椂二す相成以後何方上りなり共外々二順し世話人を立目方致 厳重持出しか一公取別可遗n……」と, 原料入荷を一層容易ならしめる方向へと進展し て来たのである。斯る規制に対する綿壳衆側の対応策が全くなからた訳ではない。松代 市場にあつては，交化13年木綿仲間取極として松代藩の了解の下に，自主的珎検査を行 い上田市場へ出荷の場合も上田の改所を経由しないよろにをなつて来た。その為，上田 城卡の海野・原両町の当番市場の市日に当つても, 繶市場を経ずして店頭へ直接送るも のが増加飞，太物仲間相互の対立にまで及んだものである。即ち，交化13年〜交政 3 年 (1816〜20)に到る5 ケ年間にわたる奥綿市場出大がそれて，上田城下の太物仲間の対立 の間隙へ奥綿売込衆の中核たる松代領や中之条代官領下の綿商人が便乗した結果がこの 争諭を展開するに到つたるのとみられる。この結果は「一, 奥綿之儀 市日二八地他共 当番市場江罷出買取猥ヶ間補儀致間敷事, 但当番市場之外二而市日居買致間敷, 店商並 二注交荷物其店江入儀市当非二不拘四ヶ町勝手次第, 目方改㙂之儀ㅅ..…市市附込荷 物之儀八当番市日之方二而相改，間日附込荷物八海野町原町改場所二而改学請町方之内 持運売様可致事」之甚だ妥協的な取決めとなつたるのである。就中，太物仲間加らの 出荷と上田城下商人が注文した奥綿の取引とは全く自由になつた点が注目され，この両 面の取引によつて，ますます充実した原料集荷の動きを示すに到つたるのと認められる。 
のみならず, 天保13年 (1842) には, これ亲で全く原料大荷のなからた上高井郡須坂 領商人からの売込か加つて来る。即ち「……所産物 (須坂領生産) 綿篠巻太物系類当御 城下江荷品持出商売致度旨……綿䈷巻二限故障筋申立以一共市町商人同士売買致情義八

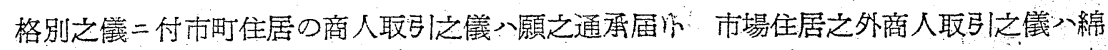
篠巻二限り難承届……と岁る。このようにして, 善光寺平に呿ける更級・植科・水内! 高井各郡生掂の奥綿は概ね上田市場の動向に影響されるが如き実情になり，い上い上上 田市場に怙ける原料集荷が北信州の中核的傾向を発揮して来たのである。

以上の検討を通じて期らかになつた如く，上田城下を中心をする小県郡下の木綿工業 は，その原料供給地域として，全国的な綿花生産の核心地域たる上方地方，地方的な生 産地たる善光寺平や甲府盈地，及び地方の中間加工的生産を営九で来た諏訪盈地等，甚 だ多様な各地域を背景としてい、たのである。この他，全国の核心的地域の一たる三河・ 遠江地方や関東平野中央部等からの原料移入，或は全国市場の消費中心であつた江月か らの原料移大などもあつたのかとも思われる。しかし，それらの動向を明示するが如き 資料は全く求められ机ので, これらの各地と直接・間接の取引があつたか否かの断定は 今後の検討を俟つことにしたい。

後期に攻んで上述の如き複雑な原料集荷が認められる事実は, 上田城下の太物仲間が 甚だ有力な取引活動を展開して来たことを如実に示すすのでめり，彼等によつて集荷さ

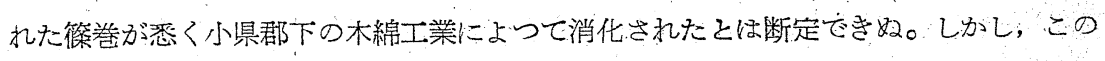
太物仲間を中心とする小県郡下の木綿工業が，これらの原料の大半を加工する程の充寒 を示していなかつたとすれば，原料集荷にみられる諸動向も上述の如き内容を具備する までに到らなかつたものと言わねばなるまい。従つて, 斯椂に複雑且活動的な原料集荷 の背景として，その集荷活動の展開を充分可能ならしめる程度の木綿生産活動が上田城 下の町々や城下周辺村々肢び領内全域にわたつて展開されていたであるろと認めざるを 得ないのである。

\section{（4）藩政後期の生産活動と移出範单}

イ、織元, 織子的生産形態

さて，上述の如き原料集荷の原動力となり，小県盈地の木綿工業の中核を形成してい た上田の太物仲間は, 文化年間 $(1804 \sim 17)$, 原町 $41 \sim 35$ 人, 海野町 $19 \sim 15$ 人, 節町 $10 \sim$ 6 人, 横町 $7 \sim 4$ 人它合計 $77 \sim 60$ 人を以つて構成されていた。この数は文化 1 年より 
12 年に到る間の变動を示したもので，合計つ上ではこの期間に脱退 8 名加入 25 名がみら

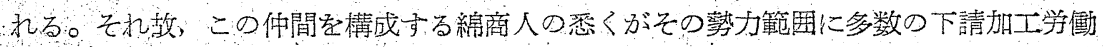
者惩属させていたとは認如難く、中には自家用の原料学求める者や自己生産が目標の. 小規模加工者への供給军主とした，小資本の綿商人る少なからずあつたすのと思う。し かし，相当の資本を有する有力な綿商人は愁く下請業者齐略々固定的々集めていたとの

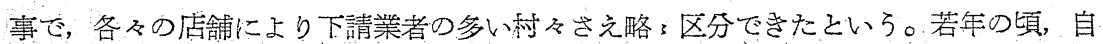

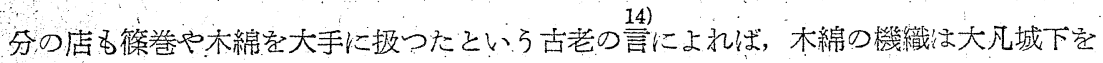
中心に $2 \sim 3$ 里範用の村ふの農閉余業る目的とする女子に委䄈る事が多かつたとい。 この人達は，秋の収穫がすむと最初 1 反分の篠巻を受取り，それが木綿になつたら店へ 持参してまた次の 1 反分の原料㕝持帰るのが一般であつた。きた，城下町やその近くの 村々には年間を通じて機織りをす人々も多く，その人々には相当量の篠巻を渡すのが常 で, 織り賃の前貸るょくみら玌たといら。但，篠巻より撚系を作るだげの下請が存在し たか否かは不明であるが，この上万な零細加工による生産の白木綿は, 小牧, 諏訪形つ 漂白業者へ「さらし」に出されたるので，就中，小牧には半ば尃門化した下請の「さら 乙屋」が多く，それらす各々固有の綿問屋を得意先とする場合が常であつをという。れれ

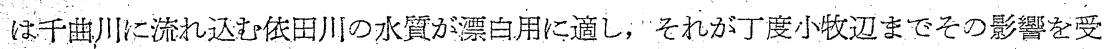

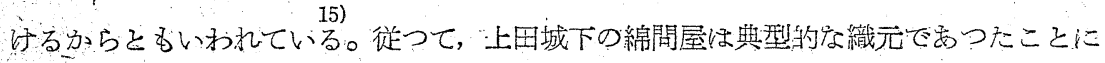
なり，その下請は大きく区分して，年間を通す織子と農閉期だけを主とする者攻び漂白

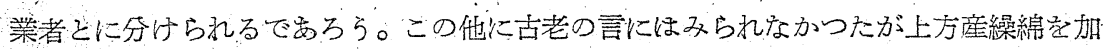
工する綿打と撚子があることは明らかで，唯，糸取りだけの下請や「かな染」の紺屋が

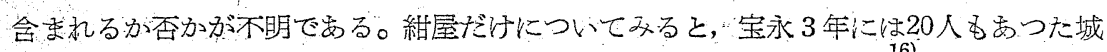
下の綪屋す明治 5 年 (1872) には僅か 7 人に減じていることからすると, 織元による縞 木綿の生産は余り大きくなかつたと諗められよう。

口, 自営的な生産形態

一方, 古く方ら在郷商人の多くみられた上田領村々に要つては, 城下周辺の村々以外

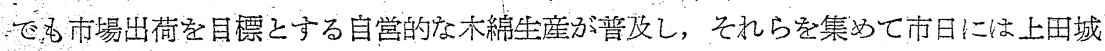
下へ売出す仲売む村々を趣つていたという。「縞木綿学沢山出されたが，これは塩田平 の濃家で織つたるので……との言がそれで, 事実, 明治12年つ町村誌には「木綿縞, 太物縞」の数量が白木綿より多い村や縞木綿だけを示声村子少くない。即ち，原料太 物仲間户諏訪，甲州等の行商加求めて加工を專らにする自営的生産にあつては，白木 
綿より複雑な工程を有する形高木綿し相 当に有利なすのとされていたことにな る。換言すれば，全然原料の生應がな く農間嫁の学賃収得を主眼とした為, 白木綿に比して相当高く取引される縞 木綿生産を主としたるのとみら秃る。 この他，自給の生糸を利用主る絹綿交 織の縞太物や綿のみによる縞太物の生 産もある。これらも多くは村々の自営 的生産によつたるのて，原粼の一部を 自給する織物生産は，一層，有利とさ れてい炎から゙あらう。これが，宝永 年間，既に相当数の紺屋職人を領内村 ふに分散させていた背景であり，安政 4 年 (1857) には, 従来, 城下緗屋町 に市つた紺屋取綃役を村々（山口，常 田, 国分寺, 大屋，下原，染地，小牧， 仁古田, 下武石, 小暤, 新㓮) に分置 する程になつた。即ち，城下よりも村 方全般しかたつて紺屋を求める場合が 多くなつていたことを示すと思う。な 特, 町树誌には縞木綿の出荷先を東京 之明示する村も認められる。或は村々 の生産の中にも在郷商人を織元とする 問屋制工業が成立していたかともみら れるが，その整証は求められない。㫿， 塩田平その他には禾綿荷物を江户へ直 接出荷する在郷商人す相当に出つたと され，“須坂商人の木綿類売込に当り太 物伸間が申立の結果認就られた市場
第 3 表 各村の木綿生産量（明治12年）

\begin{tabular}{|c|c|c|c|}
\hline 組領 & 町 村 名 & 木綿合計 & (内縞木紹) \\
\hline $\begin{array}{l}\text { 弥 } \\
\text { 䍻 } \\
\text { 領 }\end{array}$ & 鞍 于 掛 & $\begin{array}{r}\text { 反 } \\
370 \\
150 \\
\end{array}$ & $\begin{array}{r}\text { 反 } \\
250 \\
105 \\
\end{array}$ \\
\hline $\begin{array}{l}\text { 田 } \\
\text { 吉 }\end{array}$ & 大 之 屋 & $\begin{array}{l}190^{\circ} \\
147\end{array}$ & $\begin{array}{r}190 \\
\quad 0 \\
\end{array}$ \\
\hline $\begin{array}{l}\text { 国 } \\
\text { 分 } \\
\text { 寺 }\end{array}$ & 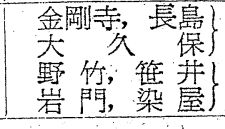 & $\begin{array}{r}750 \\
\therefore \quad 550\end{array}$ & $\begin{array}{r}? \\
?\end{array}$ \\
\hline 上 & 田 町 & 150 & $?$ \\
\hline $\begin{array}{l}\text { 塩 } \\
\text { 尾 }\end{array}$ & 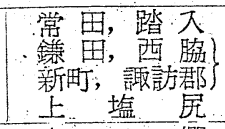 & 400 & $?$ \\
\hline 塩 & 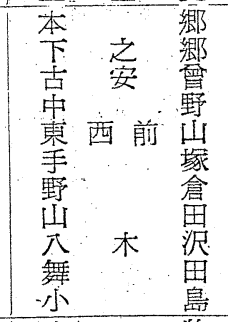 & $\begin{array}{r}800 \\
303 \\
1171 \\
1271 \\
\therefore \quad 140 \\
380 \\
\therefore \quad 240 \\
560 \\
250 \\
5 \quad 50 \\
200 \\
\end{array}$ & $\begin{array}{c}? \\
? \\
1221 \\
140 \\
? \\
? \\
? \\
? \\
? \\
200\end{array}$ \\
\hline $\begin{array}{l}\text { 小 } \\
\text { 泉 }\end{array}$ & $\begin{array}{l}\text { 小 } \\
\text { 神 }\end{array}$ & $\begin{array}{l}100 \\
410 \\
\end{array}$ & $?$ \\
\hline $\begin{array}{l}\text { 小 } \\
\text { 泉 }\end{array}$ & $\begin{array}{l}\text { 上 田 原 } \\
\text { 築 } \\
\text { 小 条 } \\
\text { 小 泉 }\end{array}$ & $\begin{array}{r}370 \\
250 \\
423 \\
3500 \\
\end{array}$ & $?$ \\
\hline $\begin{array}{l}\text { 浦 } \\
\text { 野 }\end{array}$ & 禁 克：葸 & $\begin{array}{r}520 \\
500 \\
93 \\
250 \\
\end{array}$ & $?$ \\
\hline 尾 & 野山, 飯 沼 & 2800 & 2800 \\
\hline $\begin{array}{l}\text { 埴 } \\
\text { 科 } \\
\text { 郡 }\end{array}$ & 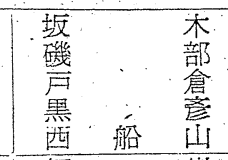 & $\begin{array}{r}700 \\
189 \\
1965 \\
1258 \\
540 \\
\end{array}$ & $\begin{array}{c}? \\
? \\
1385 \\
900 \\
?\end{array}$ \\
\hline $\begin{array}{l}\text { 更 } \\
\text { 科 } \\
\text { 郡 }\end{array}$ & 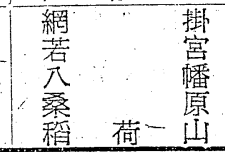 & $\begin{array}{r}950 \\
20 \\
100 \\
2000 \\
2500 \\
\end{array}$ & $\begin{array}{r}? \\
0 \\
0 \\
1800 \\
? \\
\end{array}$ \\
\hline
\end{tabular}

(明治 12年) 長野県町村誌による 
住居之外商人取引之義ハ綿筿拳二限リ難承届…..」なる禁制はこの推測を可能にするか 乙思5。

村々に扔ける分布や生産状況を明らかにするのは，生産量の把握之略了似た困難を伴 弓。第 3 表は町村誌から求めた上由市場関係の木綿生産を各町村毎に示したもので, 概 ね明治12年 (1879) 現在の状況である。即台, 木綿生産の最盛期を示すのではなく, そ の下降から消失への時期に当つている。第 3 表により明治初期の各町村に打ける状沉は 判然とするから, 詳しくは説明の要すあるまいが, 既に上田城下町やその周辺では相当 の減少が認められ，他の生産活動への転換が著るしい。な叔，千曲川以南の塩田・小泉 両組等とあつては相当の生産を示し, 上田領外の尾野山・飯沼や㨁科・更級両郡の東部 各村も同様の傾向を示している。これが期治初期に扔ける各町村の生産状況で岀る。殊 に, 一タ村て1000反以上るの産額を示す村々が相当数みられること, 縞木綿でけの生産 を示す村す少くないこと，等ばこの当時にあらても木綿生産に相当大きな関心が払われ ていたことを如実に示するのと認めなければなるおい。残念ながらすだ安政開港以前の 各村毎の状況を把えでいないので, 以上の検討に留める他ないのである。

八, 生産量と移出範囲

何れてしても，後期の生産は白木綿・縞木綿及歹び横太縞に大別され，前者は主として 城下及びその周辺村々の下請的生産により, 後二者はその他の村々に招ける自営的生産 を主とする，という形でなされたことが略 3明らかになつた。これらによりどれ程の生 産があうたか完示しろる資料は実に乏しい。各年次毎の生産量を把むのは到底でき妨 天保 4 年 (1833) 上田藩産物会所の品質検查が実施ざれるに仅び, 漸ぐ検查数量げけが 公忖にされるよろになつた。即ち，この藩営検査は領内産の絹紬・提系 (生糸) の品質 保持そ検查料による藩財政の補強を当初の目的としたるのである。これは当時の全国的 傾向と機を一にするが，養虫よりも一層の充赛を示していた木綿生産は看過される筈る なく，同様の検查を英施されたものである。この検查によつて，明らかになつた木綿生 産量は，天保14年12月～同15年 6 月 (1843〜44)に到る 7 ヶ月間に木綿4,8169反，横太 縞2,5178反, 同年7月〜11月の 5 ヶ月間には木綿1,7998反, 横太締1,1720反とあつて, この12 月間合計すると木綿 6,6167 反, 横太縞3,6898反となる。また, 弘化 1 年12月 ～2 年11月 (1844 45) では木綿5,7877反，横太䜌3, 6821反と算出されている。以上の 数量は領外出荷が目的で検查受けたすのだけを示すから領内での取引や自家消費の分は

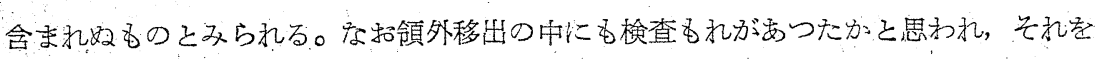




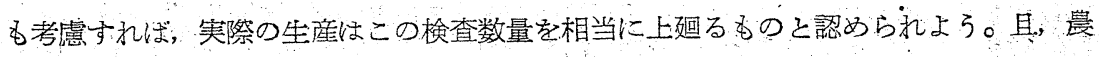
間榢の生産が加わる12〜 6 月の検査量が $7 \sim 11$ 月のるのより相当多いこと, 年間を通ず る專業的生産も著るしからたさと敒び横太縞にも年間索通す生産が認められること，等

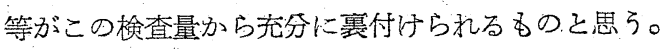

な扔，天保末年から弘化に到る時期は安政開港を直前に控えた時で，以上の数量から 汲取れる動きは，海外之の直接交渉が押えられた当時の最大の年間生産を示すすのとみ て差支え岁るまい。これらの中には善光寺平各地の生産物が上田へ送られ，上田産とし て検查を受け，他領へ送られた木綿る合まれたか否かは疑問である。しかし，善光寺・ 須坂・中野等に集荷する木綿は概柇越後・上州の各地へ送られたとされ，松代藩でる上 田々同様に産物会所の検査を略、3同時期から実施している。唯, 稳荷山市場とその近傍 7 ケ村は实質的に上田領であつたから、もしとのような動きがあつたとしてる, 稳荷山市 場のあのや, 更級・埴科両郡菒部の中之条代官領からのものが主体であつたと思われる。

移出先や移出数量を示す資料す求めら机奴が, 安政年間, 江户大荷の木綿類のらち地 ・廻品之分として，筆頭にあげられたるのは信州産の木綿である。町村誌にも移出先を武 州或は東京と明示する村ふがあり，生産量の相当部分が江戸の消費を対象としていた事 は否定てきない。佐久郡田田の一豆商は上田産の反物類を大量に買付け, 田之口藩の運 送免状を用いて江戸送りをしていたといろのもこの間の事情を裹付けている。また，綿 屋万助の取引先には，下仁田・前市・八幡山・藤山・秩父・富阙・㴕川等の関東山麓各 地がみられることからして、これらへ送られたすのあ少くなからたかとす思われる。こ の他，大䈎往還上り上州一送られた荷物にる上田出荷の木綿が相当にあり，佐众甲州往 還の木綿荷物にも上田出荷のものを認めることができる。な抬，越後魚沼郡から上田へ あ買付けにきたと言ろから上田を中心として生産された木綿類の多くは，街道・往還等 によつてこれら各地へ移出されたとみて差交えあるまい。これらの運送には, 中馬荷物 や百姓荷物によるものが少くなかつたと認められる。

\section{(5)むすび}

上述の如く，信州上田を中心に展開された木綿工業は，藩政後期，北信州一円の木綿 生産つ首位を占め, 原料は恐く他地域加求め, それにふさわ儿移出活動も認められ た。且，これは上田城下やその隣接村々だけの工業ではなく，小県盈地全般にわたつて みられた動きである。しかしながら，安政開港以降，海外市場との関係が成立すると， 
あれ程に盛んでめつた末綿工業すすつかり衰え，精々農家の自給程度に押えられ遂には 光水すら保てな小らて了万。

木綿の盛んな当時に出つても，小具産の提系，絹紬は全国的に知られ，元交年間以降， 関梖各地で名声を得ていた旦種は天保・嘉永の頃から一層の発展を示していた。且, 海 外市場との交渉により，小県が第一に要求されたるのは生系・鲁種であつた。これは木 綿の如く原料を他地域のみから求めるものではなく，なた，“新規の生産に着手する為の 困難を伴うものですなからた。即ち，既に原料生産から加工までの体険を積み，原料の 地域内自給も容易なるのでめつた。それ故，海外市場の要求と市場価格の急騰とは小県 盈地を養寔一色に好りかえるのに充分すぎるものであつたことになる。従つて，木綿生 産より養亘への転換も, 海外市場からの在来工業圧迫とみる上りは, 從来からの生㢆活 動め中で最す有利なるのケシけに集中し，その他のすのを捨ててしまつたとみるべきであ ろら。且，木綿・絹紬・提系・董種等の生産と取引によつて培われた，市場動向に対する 㚭置の態度子参与していたのである。この結果, 大正 8 年には, 上田市安除く小県の各

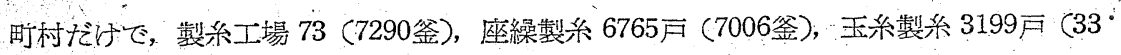
33釜)か数えられ，恰も，往時の木綿生産にみられた如き様相が展開するに到つた。 即 ら，機械製系の大工場も下請的な座繰・玉系製系る広く郡下にわたつていたのである。 全国的にみると，在来の木綿工業地域にあつてる，原料を紡績から求めて一層の発展 を示しているすのす少くない。また, 在来つ絹麻加工から木綿工業へ転向した地域も認 められる。且, 在来の木綿工業を全く失つてしまつた地域るめる。ぞの地域に招いてす， 安政開港以降の諸変動に当つて, 如何なる方向に進んだら現状が維持されより一層の発 展が可能であうろかと，種々の方向が検討されたと思う。小県盈地では最も身近の生座 活動が最も有利と目されたので，養怎関係への集中が一層容易に果されたとるられる。

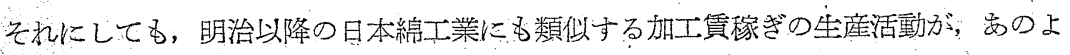
ろに古くから展開されるに到つた背景は何であろろか。それも，相当の遠距離から原料 を直接移入する程の規模を持つたすのがどらしてこの小城下町を中心に展開されたので あろろか。これらの疑䦎は上述の諸検討によつてもまだ充分に解明されていないので出 る。恐らく，これらの疑問の正しい解明は，人間の諸活動孝如何に把握するか，との立 場から綜合的に检討されて，始めて可能になるるのと思らが，今の場合は私見をあげる にとどめょう。第一は小県盈地の開発の吉さである。初期です既に一応の開発限界に達 していた事実は，㢇安 4 年 (1651) の領内総榆地による改出以降，享保 1 年 (1716) の 
改出の場合は領内(総額5, 4848石余)て嚾かに37石0994そけしか算出できなかつたこと が如美に示している。また，農業生産力の著るしい高さで岁っ。盈地中央には 2 毛作田

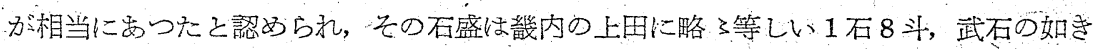
山閒の冷水掛りでる，水田の半ばは上田 (1.5石) と查定されることはこれを裏付けてい， る。従つて, 盆地内の人口密度もこれらに即俯した高さを古くから示したものと推測さ れ，或は当時の農業生産では飽和に近い状態を示していたかとみられる。中期初頭の村：

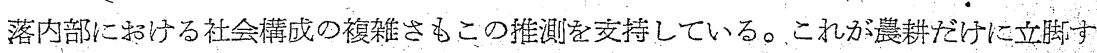

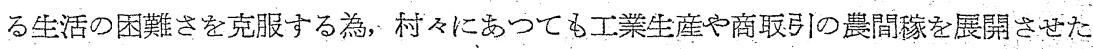
もので，山間部で原料自給の「上田縒」生産の普改促がし，平坦部ては上方からの 原料による木綿加工や自給の養虫に基く絹紬・提糸生産の一般化を進める原動力とみる

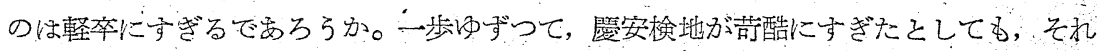
に耐光てそれ超え得る代けの勢が既に犻成されていたすのと認めざるを得ない。それ 故にこそ，㖟期の著しるい展開が示されれたの゙あり，また，明治以降の動きもこれらが 背景となつたが故と認められるすである。

〔註〕1) 宮下交書 36. 繰綿仲間一札(寛交12年)

2) 同 29. くり綿任切之覚 (寬文10年)

3) 上田図書館藏, 原町問屋日記拔書

4) 楖沢交書 交15の 1 口上書一札（享保14年）

5) 綿良交書 繰綿送状

6) 同 絹紬売仕切

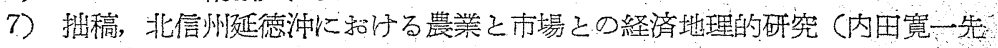
生還穈記念論交集上)

8）朝陽館漫筆

9) 平野村誌下巻 p p. $72 \sim 77$

10）綿良交畫，太物仲間当用明弁記一冊

11) 3 そ同じ

12）節沢交書 交 40 規定一札之唃

13) 10 と同じ

14）上田市原町，島甶良左衛門氏談

15）高野豊交氏調查

16）柳沢交書 記 85 上田町指出帳（明治 5 年）

17）攻び18） 3 と同じ

19）龺京市史橋 港湾篇第三，な招查京府実第三篇には的治 6 年 11 月〜 7 年 10 月迄の 1 ヶ年に1，6100反の信州産禾綿が東京へ入荷してと患る。

20）南佐久郡四田町, 井出氏談

2i）吉田交書 荷物上下大福棖

22) 北原安門氏調查

23) 小县郡史 p. 720 